\title{
Parts Procurement Planning Using the Poisson Process Method and Reliability Centered Spares
}

Muhammad Yusuf*, Imam Sodikin, Wista Wulandari

Industrial Engineering Department, Institut Sains \& Teknologi AKPRIND Yogyakarta, Indonesia

\begin{tabular}{ll}
\hline DOI:10.36348/SJEAT.2019.v04i09.009 & | Received: 20.09.2019 | Accepted: 27.09.2019| Published: 30.09 .2019 \\
*Corresponding author: Muhammad Yusuf &
\end{tabular}

\section{Abstract}

PT Intan Sejati is a company engaged in printing services. The production process at PT. Intan Sejati uses 96 machines. The maintenance activities carried out by the company are corrective maintenance. Engine damage in the period (January-December) in 2018 shows that there are 636 engine failures that require part replacement with $44 \%$ of damage occurring in the printing machine, which means the machine's printing process is a critical machine. This study was conducted to classify the criterion index part of the machine using the Reliability Centered Spares method, sorting out critical parts repairable and non repairable, determining the needs of critical parts using the Poisson Process method, determining the minimum and maximum stock quantities, determining the size of orders for economic parts using the Economic Order Quantity. The results of the RCS worksheet show that there are 3 high critical classification parts, 52 medium critical classification parts, 33 low critical classification parts and 48 not critical classification parts. The calculation of part requirements is carried out on 14 part units which are included in the high category and critical medium and have a frequency of damage $\geq 3$ times. 14 units of parts are included in the category of non repairable parts. The biggest critical part needs are on the XL 105 engine with 61 units and the smallest need is on the SM 52 A engine with 21 units. The largest maximum and minimum amount of inventory is on the CD 102 machine with a supply range of 9-26 units and the smallest inventory is on the XL 105 engine with a supply range of 2-3 units. The largest economical ordering size is on the SM 102 B engine with 11 units and the smallest on the XL 105 engine with 2 units.

Keywords: Reliability Centered Spares; Poisson Process; Criticallity Index; Economic Order Quantity.

Copyright @ 2019: This is an open-access article distributed under the terms of the Creative Commons Attribution license which permits unrestricted use, distribution, and reproduction in any medium for non-commercial use (NonCommercial, or CC-BY-NC) provided the original author and source are credited.

\section{INTRODUCTION}

PT Intan Sejati is a company engaged in the field of printing services. Products made by the company are based on orders from customers and have many variations with different process flow patterns according to the product to be produced. The production process at PT. Intan Sejati goes through three process stages namely, the design process, the printing process and the finishing process using 96 units of machinery. Each machine requires maintenance and maintenance actions so that the activities of the production process can take place as planned. The maintenance activities carried out by the company are corrective maintenance, where maintenance is carried out after the damage occurs and causes downtime. Down time at PT. Intan Sejati is divided into 3 parts, namely the down time for the engine repair process with a maximum completion time target of 1 week, the down time for the procurement of spare parts with a maximum completion time target of 2 weeks, and the third party process down time (damage to the machine that must be taken to the workshop) with a maximum completion time of 2 weeks.

Damage to the machine in the last 1 period (January-December) in 2018 showed that there were 636 times the damage to the machine that required replacement of spare parts with $44 \%$ of the damage occurring to the printing press, which means that the printing process was a critical machine. In the printing process there are 6 printing machines, namely 2 units of SM 52 type machines, 2 units of SM 102 type machines, and 1 unit of XL 105 machines and CD 102 machines respectively. The damage caused PT. Intan Sejati experienced a lot of overstocking and understocking because the system of determining spare parts inventory requirements is based on operator demand in the field, not based on a specific quantity analysis. Planning for spare parts procurement needs to be carried out to recognize the level of criticism of critical parts using the Reliability Centered Spares 
method and determine the spare parts requirements using the Poisson method.

\section{RESEARCH METHOD}

Reliability is the ability of a system or component to perform the functions required under specified conditions for a certain period of time engineering reliability is a sub-discipline in the reliability of engineering systems often measured as the probability of failure frequency failure or in the case of availability of probabilities derived from reliability and maintenance [4]. Reliability Centered Spares is an approach to determine spare parts inventory levels based on through-life costing and the need for equipment and maintenance operations to support inventory. The Reliability centered spares method consists of a series of questions, starting with how the equipment can experience failure (failure modes), then what are the effects of failure and the effect if there is a stockout (part unavailability) where it is useful to set the appropriate inventory policy for each spare part. Here are 5 basic questions in the Reliability Centered Spares method:

1. What is the need for maintenance of the equipment?

2. What happens if parts are not available?
3. Can spare parts needs be anticipated?

4. Persediaan apa yang diperlukan untuk komponen?

5. What happens if the maintenance requirements cannot be met? Critically index table can be seen in Table-1.

Table-1: Criticallity index

\begin{tabular}{|l|l|}
\hline Criticality & Criticality Index \\
\hline High Criticality & A $(4,0-5,0)$ \\
\hline Medium Criticality & B $(3,0-3,9)$ \\
\hline Low Criticality & C $(2,0-2,9)$ \\
\hline Not Criticality & D $(1,0-1,9)$ \\
\hline
\end{tabular}

(Source: Sutrisno, dkk.2015) [5]

Poisson Process according to is one method to calculate spare part needs in one period. In calculating the needs of components using Poisson Process, components are classified into repairable and nonrepairable components because the calculations use different formulas. Non repairable component is a component that if there is damage it will be immediately replaced with new components because these components cannot be repaired. The formula for calculating the need for non-repairable components using the Poisson Process method is as follows:

$$
\begin{aligned}
& \lambda_{\mathrm{t}}=\frac{1}{M T B F} t=\frac{A x N x M x T}{M T B F} \ldots \ldots \ldots \ldots \ldots \ldots \ldots \ldots \ldots \ldots \ldots \ldots \ldots \\
& \mathrm{P} \leq \sum_{x=0}^{n} \frac{(\lambda t)^{x} e^{-\lambda t}}{x !}=e^{-\lambda t}\left[1+\lambda_{\mathrm{t}}+\ldots+\frac{(\lambda t)^{n}}{n !} \ldots\right.
\end{aligned}
$$

Note : $\mathrm{A}=$ number of components in the engine

$\mathrm{P}=$ confidence level

$\mathrm{N}=$ number of machines

$\mathrm{T}=$ period

$\mathrm{M}=$ engine operating hours

Repairable component is a component that if damage occurs, the component can still be repaired. In contrast to the calculation of non-repairable

components, repairable components use MTTR values and scrap rate $(\mathrm{R})$ values. Repairable part formula:

$$
\begin{aligned}
& \lambda 1_{\mathrm{t}}=\frac{A \times N \times M \times R \times T}{M T B F} \\
& \lambda 2=\frac{A \times N \times M \times M T T R}{M T B F} . \\
& \mathrm{P} \leq \sum_{x=0}^{n} \frac{(\lambda t)^{x} e^{-\lambda t}}{x !}=e^{-\lambda t}\left[1+\lambda_{\mathrm{t}}+\ldots+\frac{(\lambda t)^{n-1}}{(n-1) !}\right.
\end{aligned}
$$

The MTTF and MTTR calculation formulas for each distribution are as follows:

Normal Distribution, $\mathrm{MTTF}=\mu$.

Exponential Distribution, $\mathrm{MTTF}=1 / \mu=\mu$

Weibull Distribution, $\mathrm{MTTF}=\eta \cdot \mathrm{r}(1+1 / \beta)$

Lognormal Distribution, $\mathrm{MTTF}=\mathrm{t}_{\mathrm{med}} \mathrm{e} \frac{s^{2}}{2}$ 
Note: $\quad \mu=$ average damage time

$\lambda=$ damage rate

$\sigma=$ standard deviation

$\eta=$ scale parameter

$\beta=$ shape parameter

The poisson process calculation factor table is as follows:

Table-2: Poisson Process Calculation Factors

\begin{tabular}{|l|l|l|l|}
\hline No & Faktor In Calculation & Symbol & Information \\
\hline 1 & Reliability value of parts & MTBF & Mean Time Between Failure (Repairable). \\
\cline { 3 - 4 } & MTTF & Mean Time to Failure (Non Repairable). \\
\hline 2 & Number of components on the machine & A & Number of components used \\
\hline 3 & Number of machine used & N & Number of machine used \\
\hline 4 & Operational time period & T & $\begin{array}{l}\text { The time between the start with request afterward (value } \\
\text { in months) }\end{array}$ \\
\hline 5 & Average machine usage & M & Operating times per day of the hour \\
\hline 6 & $\begin{array}{l}\text { Spare parts availability opportunities } \\
\text { expected }\end{array}$ & P & $\begin{array}{l}\text { Opportunities for parts are available when needed where } \\
90 \% \leq \\
\text { P } \leq 95 \% \text { Can be called also with Confidence Level }\end{array}$ \\
\hline 7 & $\begin{array}{l}\text { Average repair time period } \\
8\end{array}$ & RT & $\begin{array}{l}\text { For repairable components, known as inner time } \\
\text { improvement }\end{array}$ \\
\hline \multirow{2}{*}{$\begin{array}{l}\text { Scrap rate } \\
\text { that are in the process of repair. }\end{array}$} & R & Spare parts inventory rate additional \\
\hline
\end{tabular}

(Source: Alhilman, dkk.2017) [1]

Determination of service level is done to avoid overstocking and understocking. Determination of service levels based on criticality parts which are divided into 4 groups. The service level sample tables based on criticality index are as follows:

Table-3: Example of service level based on criticallity index

\begin{tabular}{|l|l|l|}
\hline Criticality & Criticality Index & Service Level \\
\hline High Critical A & $(4,0-5,0)$ & $99 \%$ \\
\hline Medium Critical B & $(3,0-3,9)$ & $95 \%$ \\
\hline Low Critical C & $(2,0-2,9)$ & $90 \%$ \\
\hline Not Critical D & $(1,0-1,9)$ & $75 \%$ \\
\hline
\end{tabular}

(Source: Sutrisno,dkk, 2015) [5]

The maximum and minimum stock can be calculated based on service level with the variable $M$ is the average need during the period and $\mathrm{K}$ is a factor that

$$
\begin{aligned}
& \text { Maximum stock }=M+K \sqrt{ } M \\
& \text { Minimum stock }=K \sqrt{ } M \ldots
\end{aligned}
$$

Understanding EOQ (Economic Order Quantity) "EOQ is the quantity of goods that can be obtained with a minimal cost or often said to be the optimal number of purchases", If there is a large supply of materials, the benefit is ensuring the continuity of the production process because there will be no out of material (stock out). However, the abundant supply of materials causes an increase in the cost of storing materials in warehouses. In addition, if a lot of capital is tied to inventory, it means that the capital is idle. This is certainly not efficient for the company. depends on the value of service level. Calculation of the maximum and minimum stock formulas can be seen in formulas (9) and (10). 
In connection with both of the above, it means that the amount of material inventory in the warehouse may not be small and may not be large [10]. The EOQ (Economic Order Quantity) model above can only be justified if the following assumptions can be fulfilled:

1. Demand is constant and uniform although the EOQ (Economic Order Quantity) model assumes constant demand, actual demand may vary from day to day.

2. The price per unit of constant inputting variable prices arising from quantity discounts can be handled rather easily by modifying the initial model, redefining total costs and determining optimal order quantities.

3. Constant ordering costs, storage costs per unit may vary greatly when inventory sizes increase.

The general EOQ model is in formula (11) below:

$$
\mathrm{EOQ}=\sqrt{\frac{2 \times D \times S}{I \times C}}
$$

Note: $\quad \mathrm{D}=$ Demand for one period

$\mathrm{S}=$ cost every time order

$\mathrm{C}=$ component price

$\mathrm{I}=$ fraction of holding cost

It also needs to calculate the safety stock and reorder point to find out when the company must order again and the minimum number of components in the
4. Ordering costs are constant, although these assumptions are generally valid, customer assumptions can be accommodated by modifying the initial EOQ (Economic Order Quantity) model in the same way as used for variable unit price.

5. Immediate delivery, if delivery does not occur instantaneously which is a common case, then the initial EOQ (Economic Order Quantity) model must be modified by ordering safety stock.

6. Independent inventory orders, if multiple orders produce cost savings by reducing administrative and transportation costs, then the initial EOQ (Economic Order Quantity) model must be modified again. warehouse to avoid stockout. The formulas for the safety stock and reorder points are in formulas (12) and (13) below:

$$
\begin{aligned}
& \mathrm{SS} \quad=\left(\frac{D}{\text { Number of workdays a year }}\right) \times L \\
& \mathrm{ROP}=2 \mathrm{x}\left(\frac{D}{\text { Number of workdays a year }}\right) \times
\end{aligned}
$$

Note: $\mathrm{D}=$ Demand for one period

$$
\mathrm{L}=\text { lead time }
$$

\section{RESULT}

The criticality analysis based on the RCS worksheet as a whole shows that there are 137 spare parts for each type of printing machine that must be critically analyzed. In Figure-1, an RCS worksheet recapitulation graph is presented.

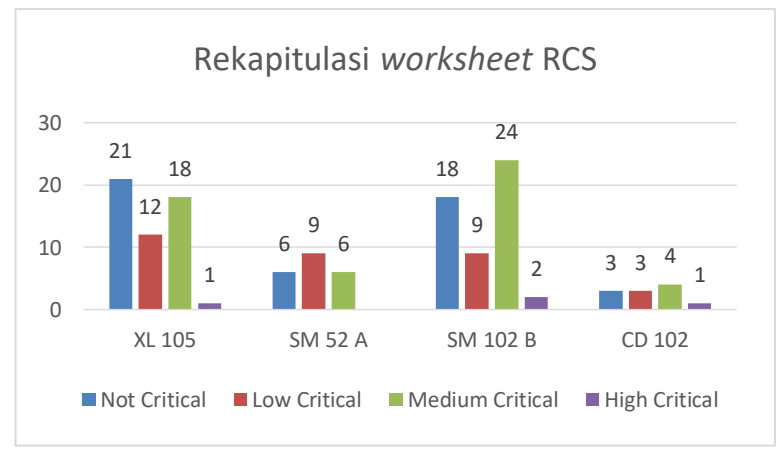

Fig-1: Recapitulation of the RCS Worksheet
Calculation of spare part requirements can be influenced by several factors, including the MTTF value, the number of components in the engine, confidence level and operating hours of the machine. In this study the confidence level used is $95 \%$ because the data needed in this study is not entirely available in the company so that the data processing is done in discussions with the maintenance company.

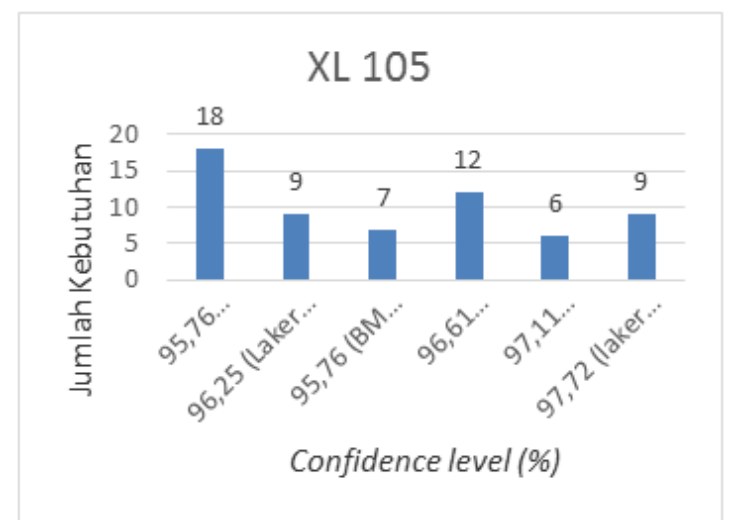

Fig-2: Inventory of spare parts of XL 105 machines with a 95\% confidence level 


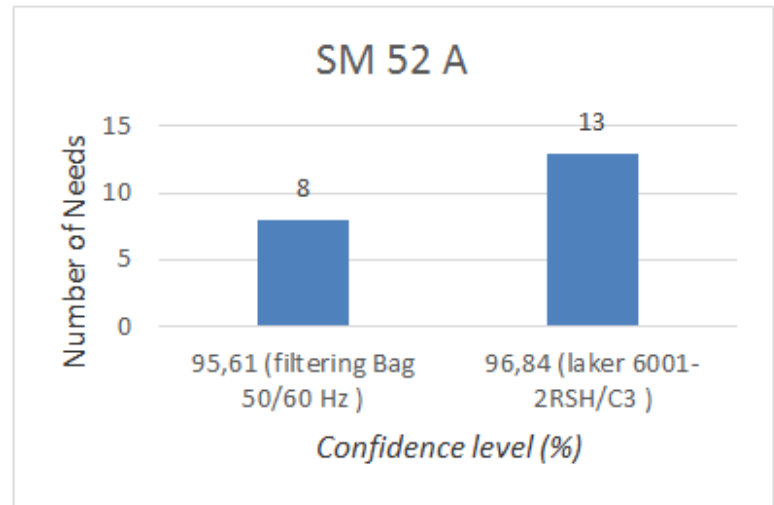

Fig-3: Inventory of spare parts of SM 52 A machines with a $95 \%$ confidence level

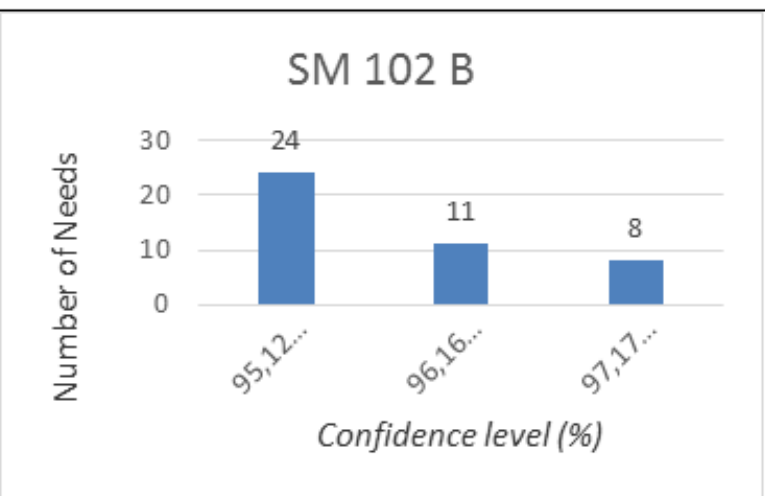

Fig-4: Inventory of spare parts of SM 102 B machines with a $95 \%$ confidence leve

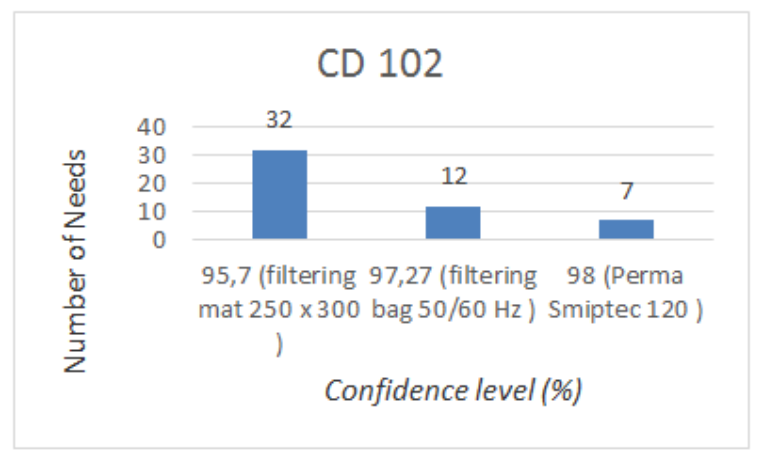

Fig-5: Inventory of spare parts of CD 102 machines with a 95\% confidence leve

Based on the calculation of the minimum and maximum inventory, the company can ensure that there is no understocking or excess inventory. The results of the calculation of the maximum and minimum inventory differ from the results of the calculation of spare part needs, this is because the calculation of spare part needs is influenced by a $95 \%$ confidence level so that the number of units needed varies according to the level of damage. In the calculation of the maximum and maximum inventory is influenced by service level spare part and stock level spare part in the company. Figure 6-9 shows a comparison of the results of calculations.

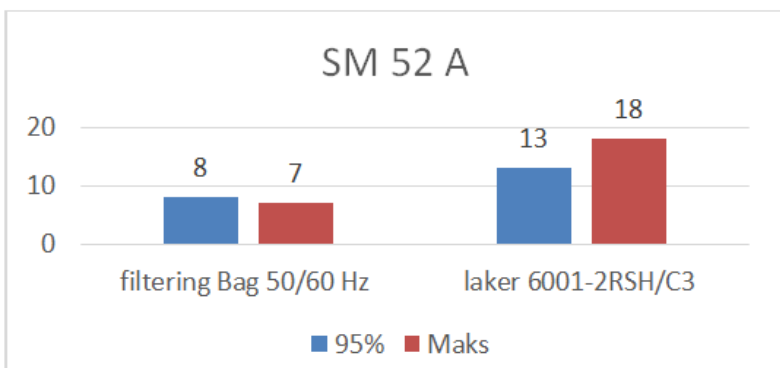

Fig-6: Calculation Results for XL 105 Machine Requirements

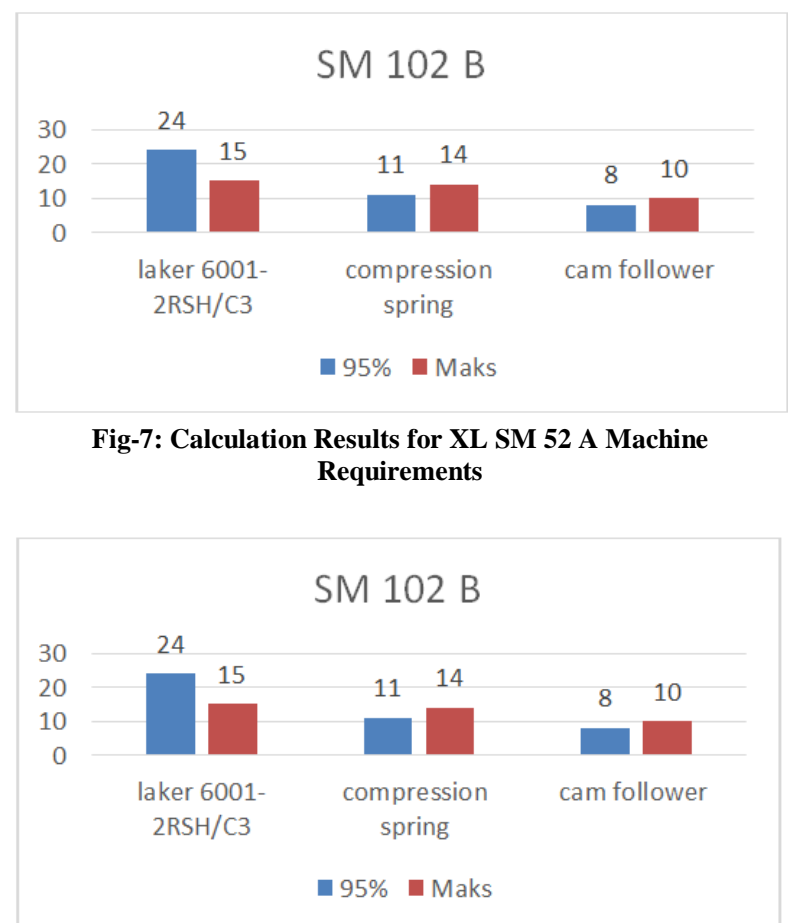

Fig-8: Calculation Results for SM 102 B Machine Requirement

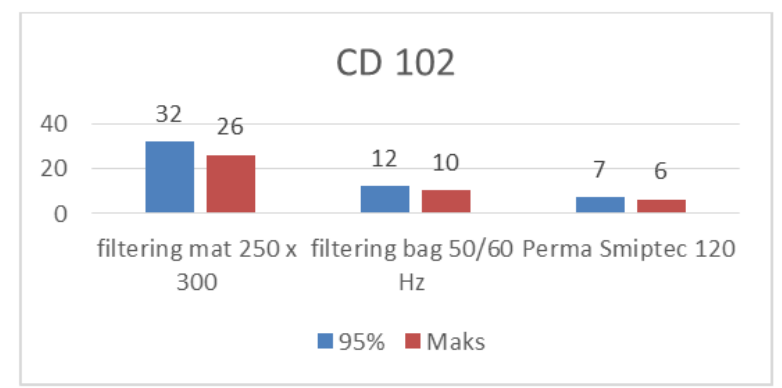

Fig-9: Calculation Results for CD 102 Machine Requirements

The EOQ method will help companies find out the optimal order quantity, safety stock and reorder points. The results of the calculation of EOQ, SS and ROP of each machine are presented in Figure 10-13 below: 


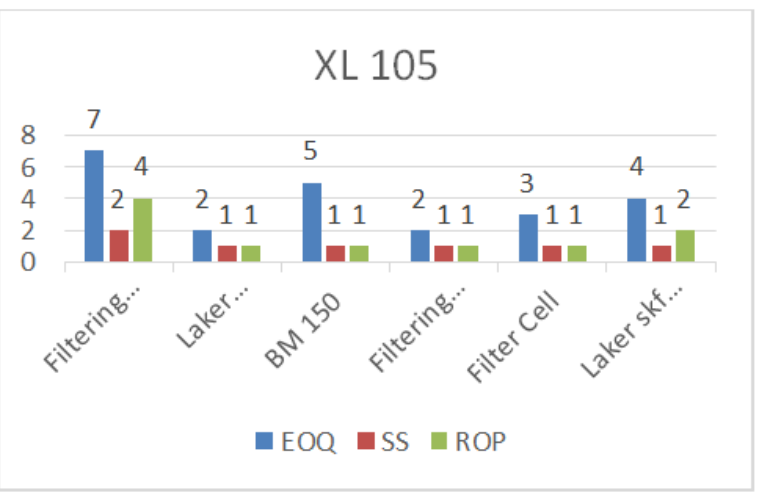

Fig-10: EOQ, SS, ROP XL 105 machines

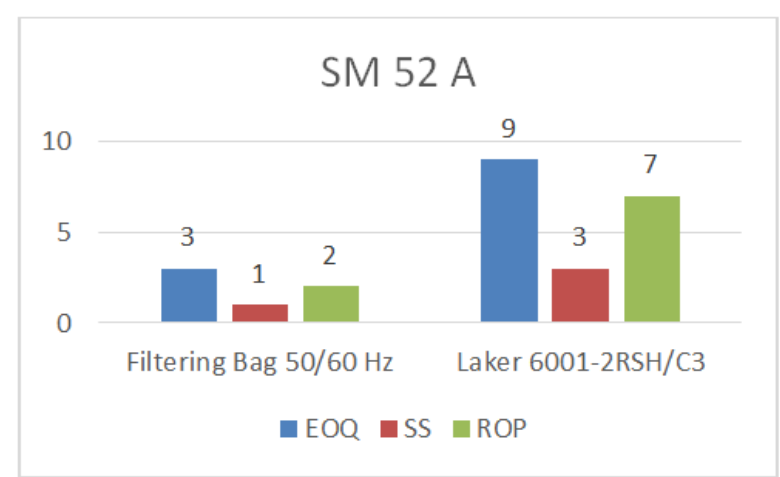

Fig-11: EOQ, SS, ROP SM 52 A machines

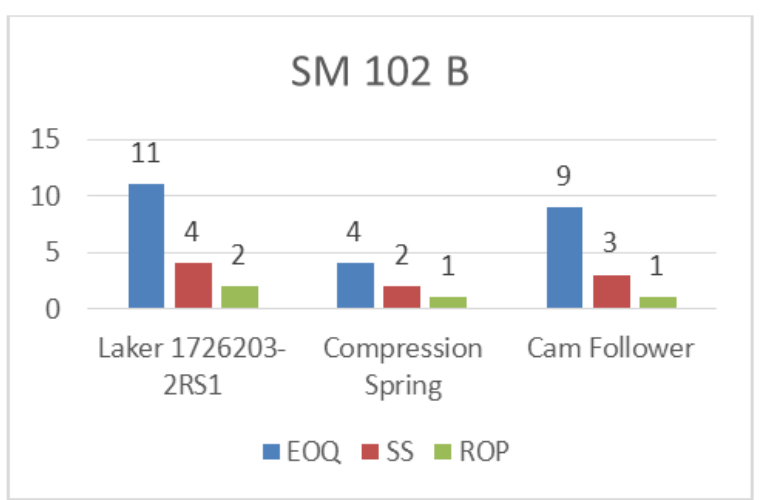

Fig-12: EOQ, SS, ROP 102 B machines

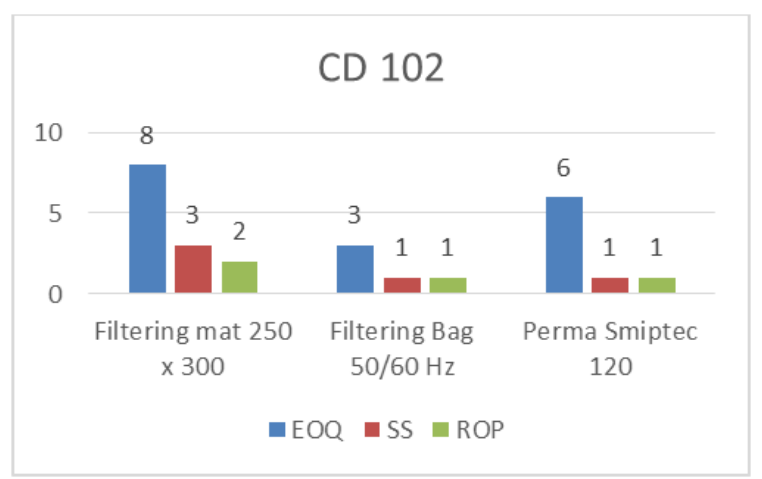

Fig-13: EOQ, SS, ROP CD 102 machines

\section{DISCUSSION}

Analysis of Critical System Selection Results, based on Figure-1 it is known that the type of printing machine that has the highest number of critical parts spare parts is the SM $102 \mathrm{~B}$ machine with a percentage of $39 \%$, the XL $10538 \%$ machine, the SM 52 A machine $15 \%$, and the printing machine with the lowest critical level, the CD 102 machine with a percentage of $8 \%$. Each spare part is divided into four levels and there are 56 parts that are categorized as high and medium critical. Spare parts with a frequency of damage that occurs <3 times during the 2018 period cannot be calculated for their inventory needs, so only 14 parts will be calculated for the needs of spare parts.

Analysis of Determination of Spares Classification, damaged spare parts at PT. Intan Sejati is divided into two classifications: repairable and nonrepairable. Includes a repairable classification if the spare parts can still be repaired with the company's maintenance system. If the damaged part cannot be repaired, it is classified as non-repairable and requires immediate replacement of spare parts. Based on the company's machine downtime data, it was found that from the 14 critical spare parts, these were spare parts that could not be reused if they were damaged so that it was classified as non-repairable. In this study to determine the distribution and parameter values using the Minitab 18 application, the damage distribution used is the Weibull and Lognormal distributions.

Analysis of Results of calculation of spare parts needs, based on Figure-2 it is known that the amount of inventory needed in the $250 \times 300$ filtering mat spare parts requires 18 units of inventory, 6205-2Z / C3 spare partlaker requires 9 units, BM 150 spare parts requires 7 units, softlow bag spare parts need 12 units, spare partfiltering cell requires 6 units, and skf 6007-2RS1 / C3 laker spare part requires 9 units.

Based on Figure 3 it is known that the amount of inventory needed in filtering spare parts Bag 50/60 $\mathrm{Hz}$ requires inventory of 8 units, and spare partlaker 6001-2RSH / C3 requires 13 units. Based on Figure 4, it is known that the amount of inventory needed on laker spare parts 6001-2RSH / C3 requires 24 units of inventory, compression spring spare parts require 11 units, and cam follower spare parts require 8 units. Based on Figure 5 it is known that the amount of inventory needed on the $250 \times 300$ part filtering mat parts requires 32 units of inventory, $50 / 60 \mathrm{~Hz}$ spare parts filter bag requires 12 units, and Perma Smiptec 120 spare parts require 7 units. 
Based on comparison of spare parts replacement data and the number of needs, it is known that using a $95 \%$ confidence level can meet the needs of spare parts so that there is no stockout, but it can still lead to excess inventory in the maintenance warehouse. This is because the calculation of needs is not influenced by inventory data factors in the maintenance warehouse, so it is necessary to calculate the maximum and minimum inventory to avoid stockout or excess stock.

Analysis of Maximum and Minimum Inventories, Figure 6-9 shows the results of the need for inventory with a $95 \%$ confidence level and based on maximum and minimum calculations. If the company uses a 95\% confidence level there will be an excess inventory stock in the warehouse on several parts in each machine. This is due to the need for spare parts that can be fulfilled with a confidence level below $95 \%$, while the results of the maximum and minimum inventory calculation using stock data and service level classification of spare parts show that the maximum amount of inventory that is smaller than the service level of $95 \%$ but can still meet request for spare parts. This can be proved by the frequency of damage to spare parts that are in the range of minimum and maximum inventory. Analysis of the Optimal order number, based on Figure 10 it is known that:

a. In the $250 \times 300$ spare part filtering mat the optimal number of orders is 7 units with 2 pieces of safety stock and re-ordering if there are 4 pieces left in the warehouse

b. In the $6205-2 \mathrm{Z} / \mathrm{C} 3$ spare partlaker the optimal order is 2 units with 1 piece of safety stock and a reorder if 1 inventory in the warehouse remains

c. In BM 150 spare part the optimal number of orders is 5 units with 1 piece of safety stock and re-ordering if there is 1 item left in the warehouse

d. In the spare part filtering bag softlow the optimal order is 2 units with the amount of safety stock of 1 piece and re-ordering if the inventory in the warehouse remains 1 piece.

e. In the spare part filtering cell, the optimal order is 3 units with 1 piece of safety stock and re-order if there is 1 item left in the warehouse

f. In the SKF 6007-2RS1 / C3 laker spare part the optimal order is 4 units with 1 piece of safety stock and re-ordering if there are 2 pieces left in the warehouse

Based on Figure 11 it is known that:

a. In the spare part filtering Bag $50 / 60 \mathrm{~Hz}$ the optimal order is 3 units with 1 piece of safety stock and re-ordering if there are 2 pieces left in the warehouse.

b. In the laker spare part 6001-2RSH / C3 the optimal order is as many as 3 units with the amount of safety stock and reorder if there are 7 pieces left in the warehouse
Based on Figure 12 it is known that:

a. In the Laker 1726203-2RS1 spare part the optimal order is 11 units with 4 pieces of safety stock and re-ordering if there are 2 pieces left in the warehouse

b. In the optimal spring spare part compression order is 4 units with 2 pieces of safety stock and a reorder if 1 inventory is left in the warehouse

c. In the cam follower spare part the optimal order is 9 units with the number of safety stock of 3 pieces and reorder if the inventory in the warehouse remains 1 piece

Based on Figure 12 it is known that:

a. In the $250 \times 300$ spare part filtering mat the optimal order is 8 units with the number of safety stock of 3 pieces and reorder if the inventory in the warehouse remains 2 pieces

b. In the spare partfiltering bag $50 / 60 \mathrm{~Hz}$ the optimal order is 3 units with 1 piece of safety stock and reordering if there is 1 item left in the warehouse

c. In Perma Smiptec 120 spare part, the optimal number of orders is 2 units with 1 piece of safety stock and a reorder if 1 inventory in the warehouse is left

\section{CONCLUSION}

Based on the results of data processing and discussion conducted previously, the following conclusions can be drawn:

- RCS worksheet shows that there are 3 high critical classification spare part units, 52 medium critical classification spare part units, 33 low critical classification spare part units and 48 not critical classification spare part units.

- There are 14 unit parts that are categorized as high and medium critical that will be counted on their needs and are included in the category of non repairable parts

- The biggest critical spare part needs are found in the XL 105 machine with the number of needs of 61 units and the smallest spare part needs are found in the 52 A SM machine with the number of needs of 21 units.

- The maximum and minimum amount of inventory is found on CD 102 machines with a range of inventory 9-26 units and the maximum amount and minimum inventory is on the XL 105 machine with an inventory range of 2-3 units.

- The largest economic order size is found in the SM $102 \mathrm{~B}$ machine with 11 units and the smallest economic order size is on the XL 105 machine with 2 units.

\section{REFERENCES}

1. Basanta, F. A., \& Alhilman, J. (2017). Perancangan Aplikasi Analisis Rcm (reliability Centered Maintenance) Dan Rcs (reliability 
Centered Spares) Dalam Menentukan Kebijakan Maintenance Dan Persediaan Spare Part. eProceedings of Engineering, 4(2).

2. Sarashvati, M. S., Alhilman, J., \& Nopendri, N. (2018). Optimasi Kebijakan Perawatan Menggunakan Metode Reliability Centred Maintenance (Rcm) Dan Perencanaan Pengelolaan Suku Cadang Menggunakan Reliability Centred Spares (Rcs) Pada Continuous Casting Machine\# 3 Slab Steel Plant Di Pt Krakatau Steel, Tbk. Jurnal Industrial Servicess, 3(2).

3. Rachmawati, I. N., Sutrisno, S., \& Rahmat, H. (2016). Perencanaan Pengadaan Suku Cadang Berdasarkan Criticality Menggunakan Metode Poisson Process dan Modifikasi Model Economic Order Quantity (Eoq) untuk Permintaan Diskrit. JRSI (Jurnal Rekayasa Sistem dan Industri), 1(1), 56-62.

4. Meilani, D., Kamil, I., \& Satria, A. (2008). Analisis Reliability Centered Maintenance (RCM) Dan Reliability Centered Spares (RCS) Pada Unit Rawmill Pabrik Indarung IV PT. Semen Padang. Jurnal Optmasi Sistem Industri, 8(1), 916.
5. Pardede, T., Saedudin, R. R., \& Sutrisno, S. (2015). Perencanaan Kebijakan Pengelolaan Suku Cadang Corazza A452 Dan Corazza Ff100 Line 3 Menggunakan Metode Reliability Centered Spares (rcs). eProceedings of Engineering, 2(2).

6. Kumar, M., \& Kumar, R. (2016). Reliability Centered Maintenace of a Ply Industry : A case Study. International Journal of Engineering Research \& Technology (IJERT), 5(11).

7. Sanjani, T., Alhilman, J., \& Athari, N. (2018, October). Proposed Maintenance Policy and Determining Sparepart Amount Using Reliability Centered Maintenance (RCM) and Reliability Centered Spares (RCS) for Eurosicma E 75 Machine. In International Conference on Information Technology, Engineering, Science \& its Applications.

8. Riyanto, B. (2001). Dasar-dasar Pembelanjaan Perusahaan, Cet.7, BEP, Yogyakarta.

9. Prawirosentono, S. (2013). Manajemen Operasi Analisis dan studi kasus PT. Bumi Aksara, Jakarta.

10. Petty, W. (2005). Financial Management: Principles and Application 10th ed. New Jersey, Prentice Hall. 